\title{
Comparative analysis of sustainable value distribution for stakeholders in the mining industry
}

\author{
Sylwia Lorenc ${ }^{1, *}$, Arkadiusz Kustra ${ }^{1}$ \\ ${ }^{1}$ AGH University, Department of Economy and Management in Industry, 30 A. Mickiewicz Av., 30- \\ 059 Kraków, Poland
}

\begin{abstract}
The objective of this article is the analysis and comparison of the value distribution process that takes place in enterprises for stakeholders. The following coal mining enterprises are subject of this work: JSW S.A., KGHM S.A., and LW Bogdanka S.A, for which the directions of value distribution in the years 2011-2016 were presented. The article defines the main groups of the partnerships' stakeholders, such as the owners, staff, suppliers, equity providers, the country budget and the local governments' budgets. The sustainable value benchmark was defined as the benefits received by the stakeholders through the allocation of financial surplus. The value defined for the abovementioned stakeholders was assessed according to the Free Cash Flow (FCF) methodology.
\end{abstract}

\section{Introduction}

Approaching a company's value in a way that is most beneficial to the shareholders' is no longer a current approach; especially considering the economy both at home and around the world. As Hop and Kudełko show, the current market conditions try to force companies to look for new ideas to achieve competitive advantage and gradually increase company's value [1]. Departing from traditional ways of value assessment, which are partly based on the shareholder theory, brought more attention to stakeholders of enterprises who either directly or indirectly contribute to the process of working out a company's economic success [2]. As the ideas of sustainable development and corporate social responsibility are developing, one can see a growing interest in building the sustainable development value of an enterprise based on meeting the needs of all the stakeholders of a given company (the stakeholder theory). It also stresses the need to adapt companies not only to legal requirements in this area, but also to carry out additional activities in the area of investing in human capital, environmental protection and stakeholder relations [3]. This is due to the existence of a contract theory according to, an enterprise consists of a set of contracts where the groups of stakeholders provide the enterprise with certain resources (skills, goods and services, cash and capital) and in return receive real benefits such as dividends, remuneration, earned interest, goods and services, taxes and financial donations [4].

\footnotetext{
"Corresponding author: slorenc@agh.edu.pl
} 
Nowadays, there are several tools of value assessment for owners, both in science and in business. However, there is no offer of effective tools to measure sustainable value [5]. Creating a universal measurement tool is, therefore, a challenge to modern researchers. The difficulty in doing so lies mainly in the multidimensionality of the value assessment concept, as well as in the possibility of linking it with the idea of sustainable development, the dynamics of changes that take place in specific disciplines and in lack of clearly defined concepts in this area.

\section{The model of sustainable value assessment based on the Free Cash Flow to Firm (FCFF) methodology}

By meeting the needs of all its stakeholders, an enterprise creates sustainable value, at the same time ensuring that the objectives of sustainable development are achieved in the areas of economics, the environment, and society. Taking voluntarily into consideration the interests of communities and the environment, the expectations and needs of stakeholders, as well as the realization of value added for these groups makes a company socially responsible and seems to be one of the better ways of achieving market success [6].

According to Morley's assumptions, value added generated for stakeholders is the margin left from deducting current costs (the purchased goods and services) from the sales income [7]. Therefore, it constitutes a surplus that is distributed among beneficiaries, i.e., stakeholders. In return for tangible and intangible contribution to the organization's success, groups of individuals associated with the enterprise receive a reward in the form of 'social dividend', i.e., contribution to the staff, equity providers, shareholders, the Treasury, and others [8]. Thanks to their relationship with the enterprise, stakeholders benefit from remuneration and bonuses, pensions, loan interests and dividends, as well as taxes or profits from the long-term relationship with the business.

Defining the value that is distributable to a company's beneficiaries is made possible by using income methods, concepts of free cash flow, and operating and financial costs.

An appraisal of value added by means of cash flow calls for an application of the new concept of free cash flow from value added (FCF VA). It refers to the sum of cash flow for the respective groups of beneficiaries: owners (FCFE, i.e., Free Cash Flow to Equity), staff (FCFW, i.e., Free Cash Flow to Workers), equity providers (FCFD, i.e., Free Cash Flow to Debt), suppliers (FCFS, i.e., Free Cash Flow to Suppliers), municipal administration (FCFM, i.e., Free Cash Flow to Municipal Administration), and the state (FCFSt, i.e., Free Cash Flow to State). While for these groups the value distributed by the company constitutes a cash inflow benefit, for the company it is an expense related to cost [9].

Based on the above, free cash flow for owners was determined as a derivative of profit, depreciation, investments expenses, net working capital needs, and principal installments.

Cash flow to staff results from remuneration and other benefits.

Cash flow to banks comes from interest rates and principal installments payable to them.

Cash flow to suppliers results from product-related costs, power supply costs, and external services provided to the company.

Cash flow to counties, municipalities and the state is the derivative of taxation, fees, and income tax payable to them.

The methodology based on generic registry in the area of operational activity and used herein, together with value assessment for all stakeholders is legitimized by the necessity of putting total costs of business units in a bigger perspective. It seems reasonable to have a multidimensional perspective for companies' business activities and to consider all the costs in this regard. An overgeneralization of cost examination can result in insufficient data in the area of creating a real value for interest groups [10]. 
Sustainable value and the possibility of creating it become considerably important in the case of mining enterprises which have a major influence on different aspects of sustainable development. Sustainable development in mining requires not only a steady economic growth or social responsibility, but it also should protect natural resources and the environment by means of a reasonable exploitation of the resource or reduction of adverse effects that mining activities have on various forms of geological environment. Sustainable development in mining industry, thanks to a holistic approach to an enterprise and specific, assessed benefits to the society, can be a verification tool for a company's profitability with regard to liquidation or continuation of business activities, based on its current and prospective influence on immediate and more distant environment.

\section{Analysis of Value Distribution}

Analysis of value distribution was performed for the three largest domestic mining partnerships: Jastrzębska Spółka Węglowa S.A. (the largest producer of high quality coking coal), Lubelski Węgiel Bogdanka S.A. (provider of energy coal to power plants and heat and power stations, being one of the leading providers of black coal in Poland and proudly excelling in financial results and in efficiency of black coal exploitation, as well as in investments plans that aspire to explore new deposits), and KGHM Polska Miedź S.A. (one of the largest state-owned enterprises and a major producer of copper and fine silver in the world).

The abovementioned businesses are active in the area of sustainable development; for example, by following the social responsibility strategy. As listed companies, they make public their sustainability effects in CSRs and in integrated reports. Because of this, it is possible to create a positive image of the sector, which translates into value realization for shareholders and other stakeholders. Taking all this information into account, it seems that these enterprises can serve as benchmarks of good business practices; they may also constitute a starting point of this analysis.

A research method that combines both accrual and cash approaches allowed for the analysis of the distribution of the value generated by these enterprises from 2011 to 2016. The study was based on the official data made publically available in the financial reports issued by them.

The assessed and presented benefits that these partnerships produce were allocated to the respective groups of stakeholders. For the years that were examined, it was determined what the benefits amounted to financially as they reach the respective value beneficiaries.

The starting point of the analysis was the determination of free cash flow from value added FCFF VA, that is, the total value generated by the enterprises for their stakeholders from 2011 to 2016 (Fig. 1).

The analysis of the selected partnerships in terms of their capability to meet the financial needs of their stakeholders showed a varied pattern in value shaping.

In the case of LW Bogdanka S.A., a drop in total profits took place in the years 2013 to $2014(6 \%)$. The highest dynamics of change was observed in the years 2011 to 2012 (growth of $110 \%$ ), from 2014 to 2015 (growth of 24\%), from 2012 to 2013 (growth of $10 \%)$. An increase more than twofold (110\%) resulted from the shift in cash flow to owners (negative FCFE in 2011; positive FCFE in 2012), while the $24 \%$ growth was the consequence of the change in cash flow for the financing entities (FCFD). In the years of 2011 to 2016 total added value based on cash flow generated by the company for the selected stakeholders amounted to PLN 7, 746. $6 \mathrm{M}$. 


\section{FCF VA [mln PLN] $\quad$ FCF VA}

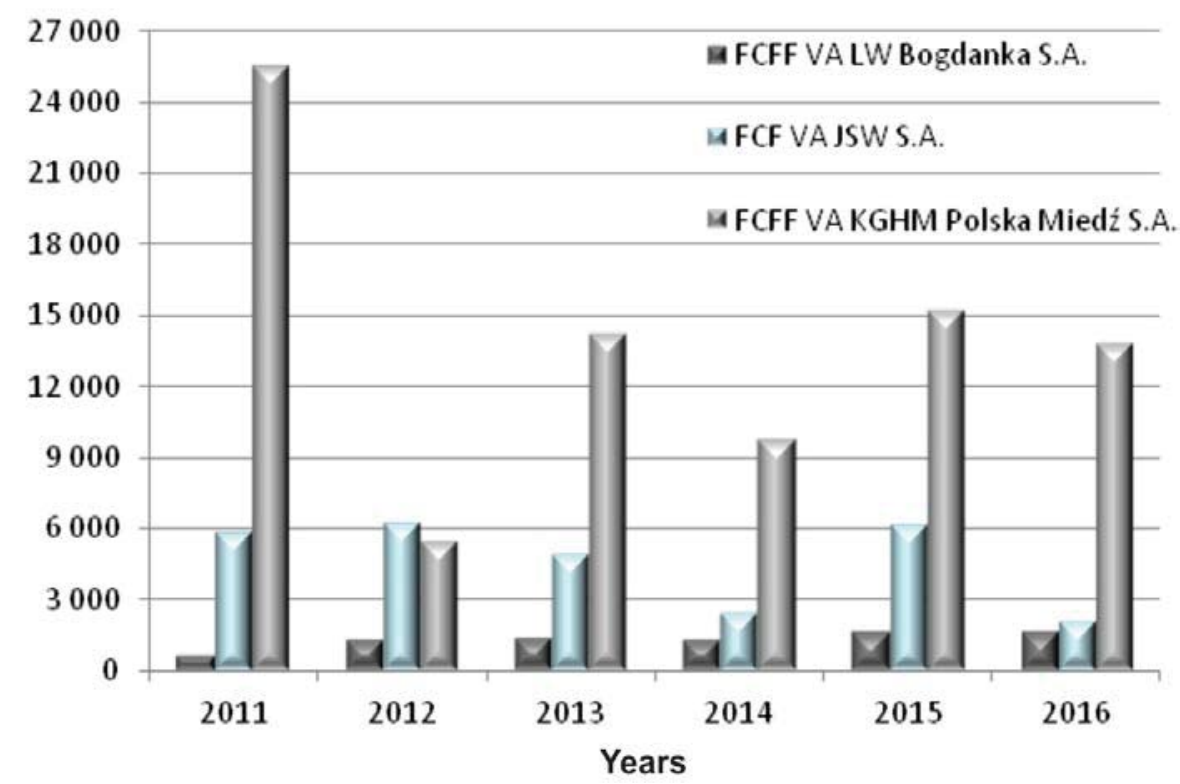

Fig. 1. FCF VA for all stakeholders generated by the analyzed companies in 2011-2016. Based on company data [11-13].

As far as JSW S.A. is concerned, there was a decrease in total cash flow generated by the company between 2012 and 2013 (21\%), from 2013 to 2014 (51\%) and from 2015 to $2016(66 \%)$. The change was most dynamic between 2014 and 2015 (growth of 156\%) and in the years 2011 to 2012 (growth of 7\%). A more than double increase (156\%) was caused mainly by the change in cash flow to creditors (a major negative FCFD in 2014; positive FCFD in 2015). On the other hand, an increase between 2011 and 2012 resulted from the reduction of negative values of cash flow for this particular interest group (FCFD). In the years between 2011 and 2016 total added value based on cash flow generated by JSW S.A. for stakeholders reached PLN 27, 606.3 M.

Nevertheless, KGHM Polska Miedź generated the highest value for its stakeholders, PLN 83, $959.0 \mathrm{M}$. The company saw the most dynamic change between 2012 and 2013 (increase of 161\%) and between 2014 and 2015 (increase of 55\%). A nearly triple increase (161\%) was the effect of cash flow to ownership and banks (a major negative FCFE and FCFD in 2012; positive FCFE and FCFD in 2013), while the increase of 55\% was due to reducing major negative cash flows to financing units FCFD and owners FCFE. A decrease in total value was observed between 2011 and 2012 (79\%), from 2013 to 2014 (31\%) and between 2015 and 2016 (9\%) and was determined by the decline in FCFD and in FCCFE that reached negative values.

Figures 2-7 show the shaping of cash flow to those respective stakeholders who have their share in the value generated by the companies. The value is distributed in such ways as by remunerating and granting benefits to employees, paying taxes to municipalities and the state, earning interest by equity providers, paying dividends to ownership, and giving profits to goods and services providers. 


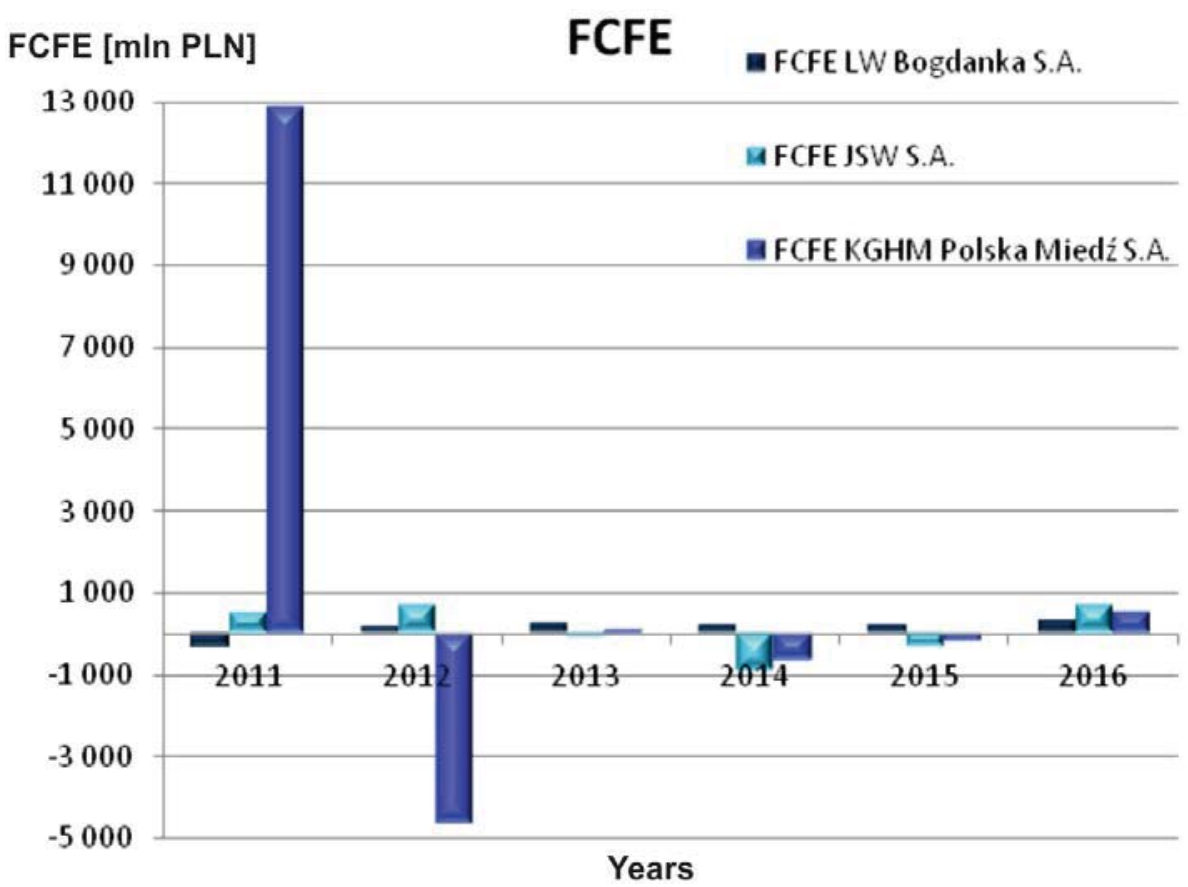

Fig. 2. FCF to equity in 2011-2016. Based on company data [11-13].

The analysis of the value created for the owners by the abovementioned units (Fig. 2) is reflected in the reported profits and losses for this interest group.

With regard to LW Bogdanka, the company generated positive cash flow between 2012 and 2016, with the exception of the year 2011, when, due to expenses incurred by investments (increase in fixed assets) and a bigger demand for net working capital, a negative value for this particular interest group was observed.

In the examination of business activity in JSW S.A., the years 2013, 2014, and 2015 show a negative cash flow to ownership. It indicates the necessity of providing the company with funds and, to a large extent, it is the result of major investment expenses and negative net profit. A positive value for this stakeholder can be seen in 2011, 2012 and 2016.

With respect to KGHM Polska Miedź S.A., a positive value for its owners was recorded in 2011, 2013 and 2016. The other years saw negative cash flow, the main reason of which was significant investments costs, negative net profit (net loss), and an increase in demand for net working capital.

Investments in fixed assets are one of the most common reasons that influence the level of cash flow to the owners. Investments freeze the accessible resources and lower FCFE. Nevertheless, taking into consideration the expenses in the long run, they are necessary to maintain and further generate current cash flow. Without investment costs, a steady development of companies is not possible.

Among the examined businesses, KGHM Polska Miedź S.A. provided its owners the highest value in 2011, that is, PLN 8,045.8 M. The lowest value for this company was observed in 2012 and it amounted to PLN to 5, 007.4 M.

Equity providers constitute a group of stakeholders that, within the examined period of time, benefits the least from their relationship with the enterprises (Fig. 3). 


\section{FCFD $[\mathrm{m} \ln$ PLN $] \quad$ FCFD}

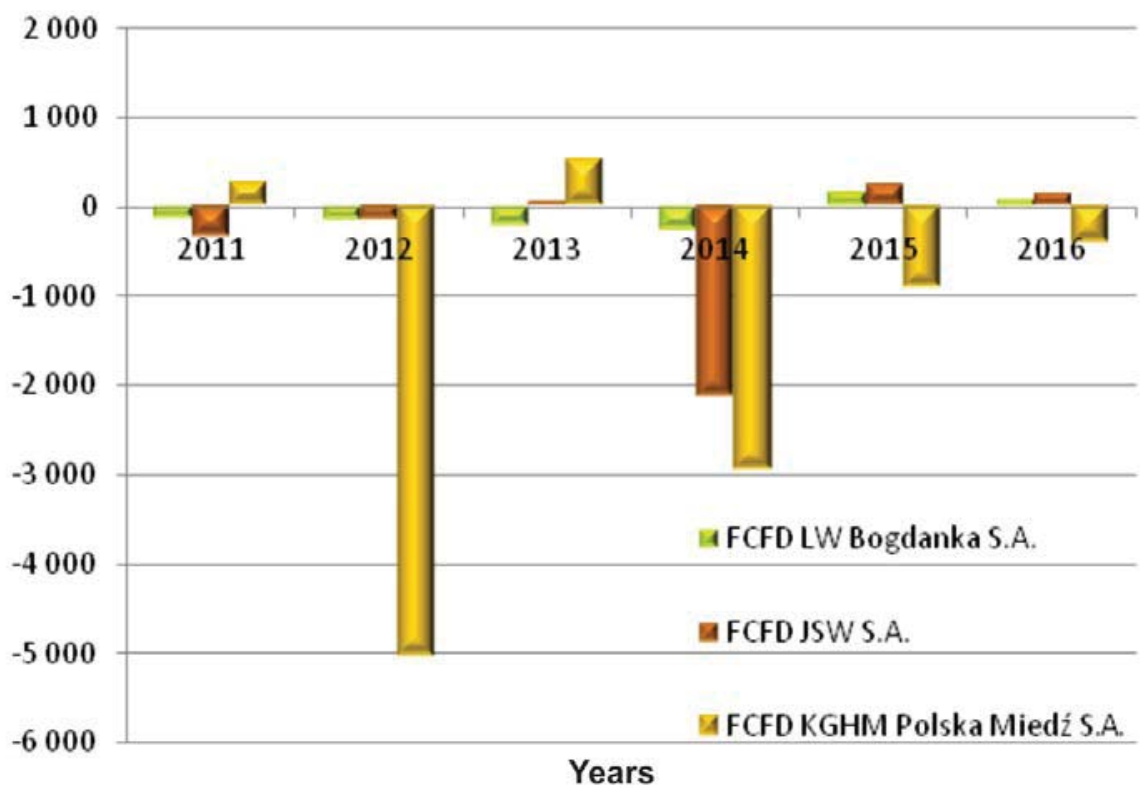

Fig. 3. FCF to debts in 2011-2016. Based on company data [11-13].

With regard to LW Bogdanka S.A., for the years 2015 and 2016, little value was recorded, namely, the generated profits were, respectively, PLN 170.5 M and PLN 79.7 M. Regardless of that, free cash flow to banks, for the majority of the examined years, shows negative values. In the period of 2011 to 2014 the banks did not benefit from their relationship with the enterprise.

Taking into account the results achieved by JSW S.A., a positive value for this stakeholder was reported in 2013, 2015, and in 2016, while during the other years the cash flow was negative. The year 2014 had the highest losses; that year saw the lowest value of PLN 2, 103.3 M.

KGHM Polska Miedź S.A. generated a positive value for equity providers only in 2011 and 2013. In the other years, the analysis shows strong negative values of cash flow for this group of stakeholders.

Negative values of cash flow to banks are the findings of analysis that is based on cash flow approach. Despite positive interest on loans that the banks receive on a regular basis and which the companies regularly pay off, there is a problem with high values of capital installments that are significantly higher than the interest. Negative values of capital installments are the consequence of an increase in foreign capital in the examined period of time. The implication is that, while the businesses take new loans, the banks benefit only from the interest payable to them. The exception applies to the years when foreign capital decreased, which further implies that businesses pay off capital installments, which in turn confirms an increased profit for equity providers. 


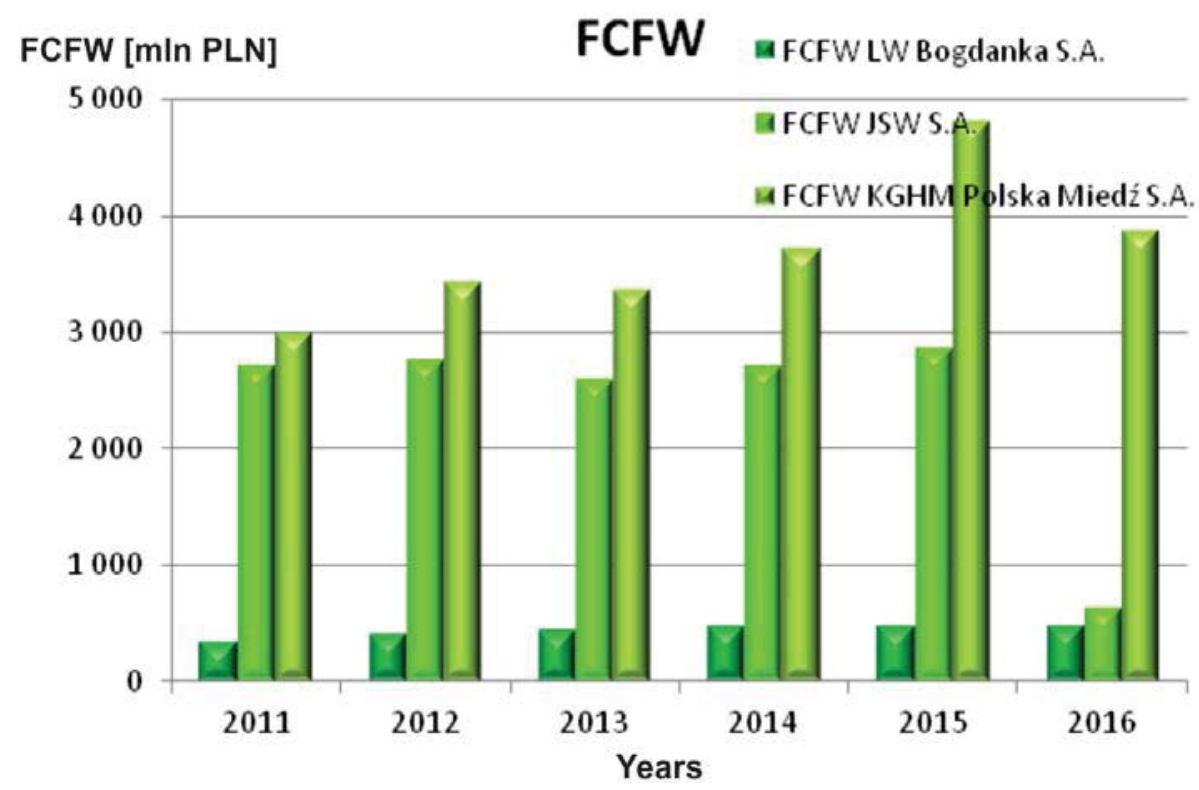

Fig. 4. FCF to workers in 2011-2016. Based on company data [11-13].

Employees are the group most closely related to businesses. It is confirmed by the fact that, through the relationship with the business they work for, employees are the main value beneficiaries (Fig. 4). Cash flow to this group fluctuates around the average amount of PLN 435.0 M for LW Bogdanka S.A., PLN 2, 380.9 M for JSW S.A., and PLN 3, $700.6 \mathrm{M}$ for KGHM Polska Miedź S.A. The largest remuneration and benefits intended for distribution to staff was recorded in 2015. They amounted to PLN 4, 809.8 M and belonged to KGHM Polska Miedź S.A.

The suppliers are the second largest value beneficiaries of the examined businesses (Fig. 5). KGHM Poska Miedź S.A. generated the biggest profit for them. Such was the case in 2015 when the total amount was PLN 9, 580.8 M. In this respect, LW Bogdanka achieved the lowest score, namely, PLN 712.0 M on average reached the suppliers through the purchases of power resources and external services. Considering JSW S.A., the average values oscillated around PLN 2, 023.5 M, while KGHM Polska Miedź S.A. had the average value at the level of PLN 7, 871.6 $\mathrm{M}$ for its suppliers.

The businesses generate the lowest positive value for municipalities (Fig. 6). On average, funds payable to local governments' budgets as taxes and fees amount to PLN 27.5 M for LW Bogdanka, PLN 146.5 M for JSW S.A., and PLN 1, 446.0 M for KGHM Polska Miedź S.A. The biggest profit that this group of stakeholders earned was generated by KGHM Polska Miedź S.A. in 2015 and it equaled PLN 1, 985.9 M. LW Bogdanka S.A. had the lowest value of PLN $19.8 \mathrm{M}$.

The process of added value distribution in terms of profits earned by the Treasury (Fig. 7) indicates that this interest group had the highest income in 2011. In that year of the analysis, KGHM Polska Miedź S.A. paid the Treasury an income tax of PLN 2, 300.0 M. As opposed to this, the lowest value for this company was reported in 2015, that is, PLN 113.0 M (income tax return). The average liabilities that go in the Treasury vary around PLN 64.4 M each year for LW Bogdanka S.A., PLN 317.6 M for JSW S.A. and PLN 1, 043.3 M for KGHM for Polska Miedź S.A.

For all the three enterprises, a detailed analysis of value distribution for the abovementioned groups of stakeholders is presented in Figs. 8, 9 and 10. 


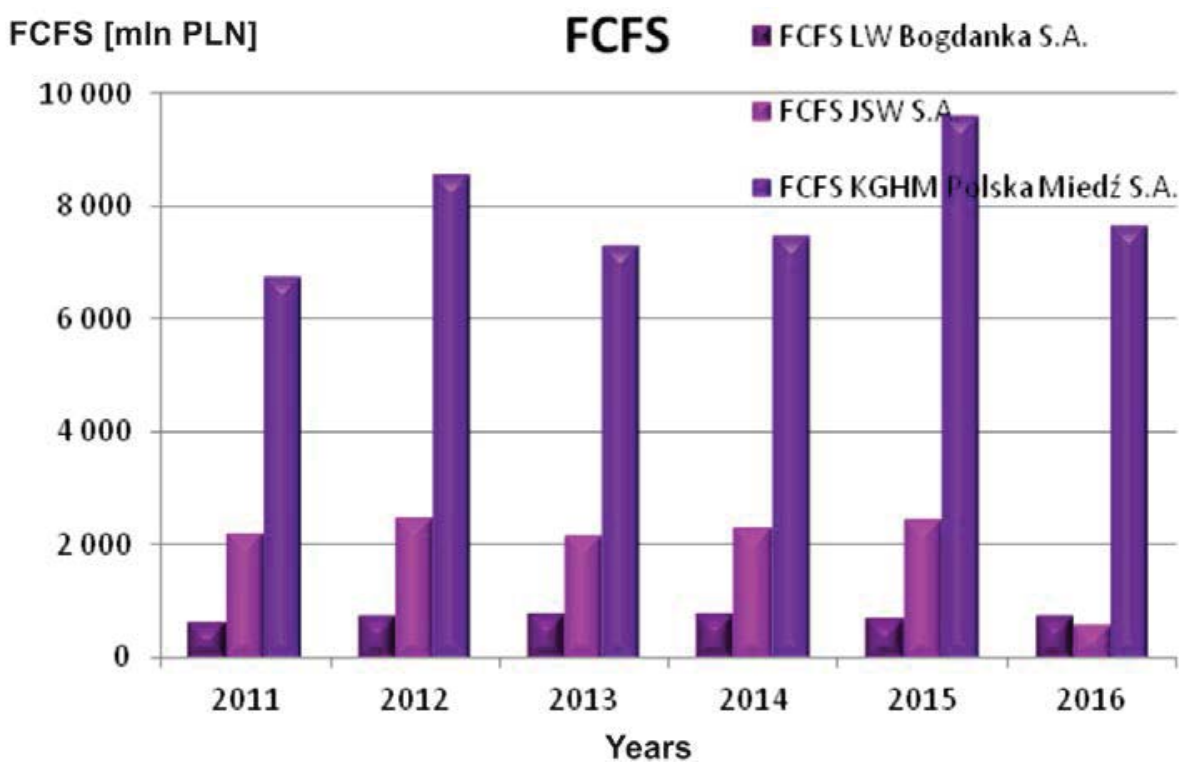

Fig. 5. FCF to suppliers in 2011-2016. Based on company data [11-13].

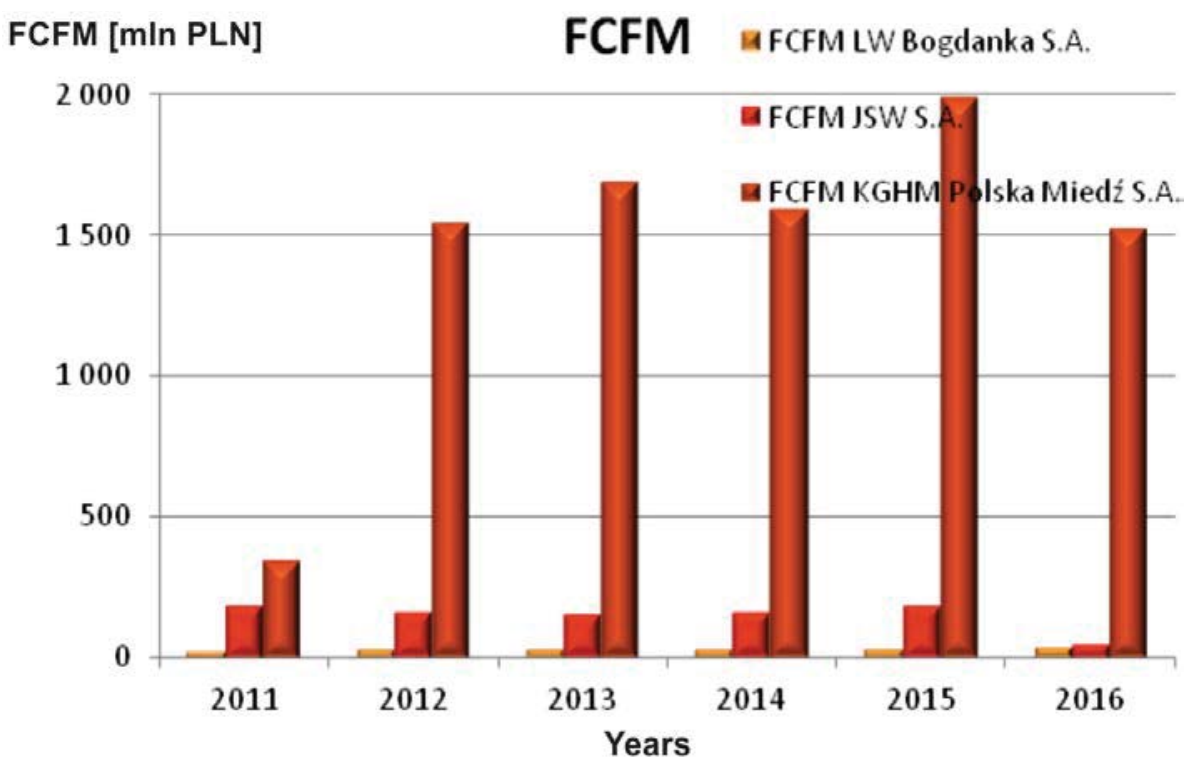

Fig. 6. FCF to municipal administration in 2011-2016. Based on company data [11-13]. 


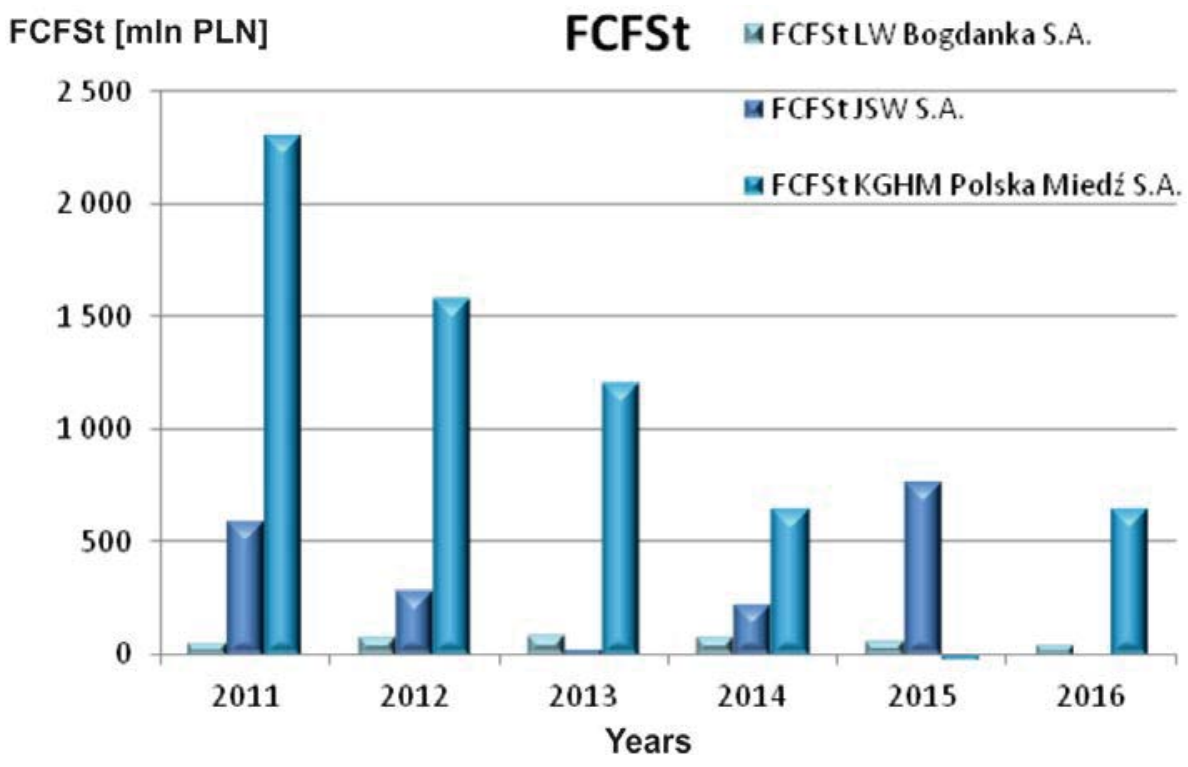

Fig. 7. FCF to state in 2011-2016. Based on company data [11-13].

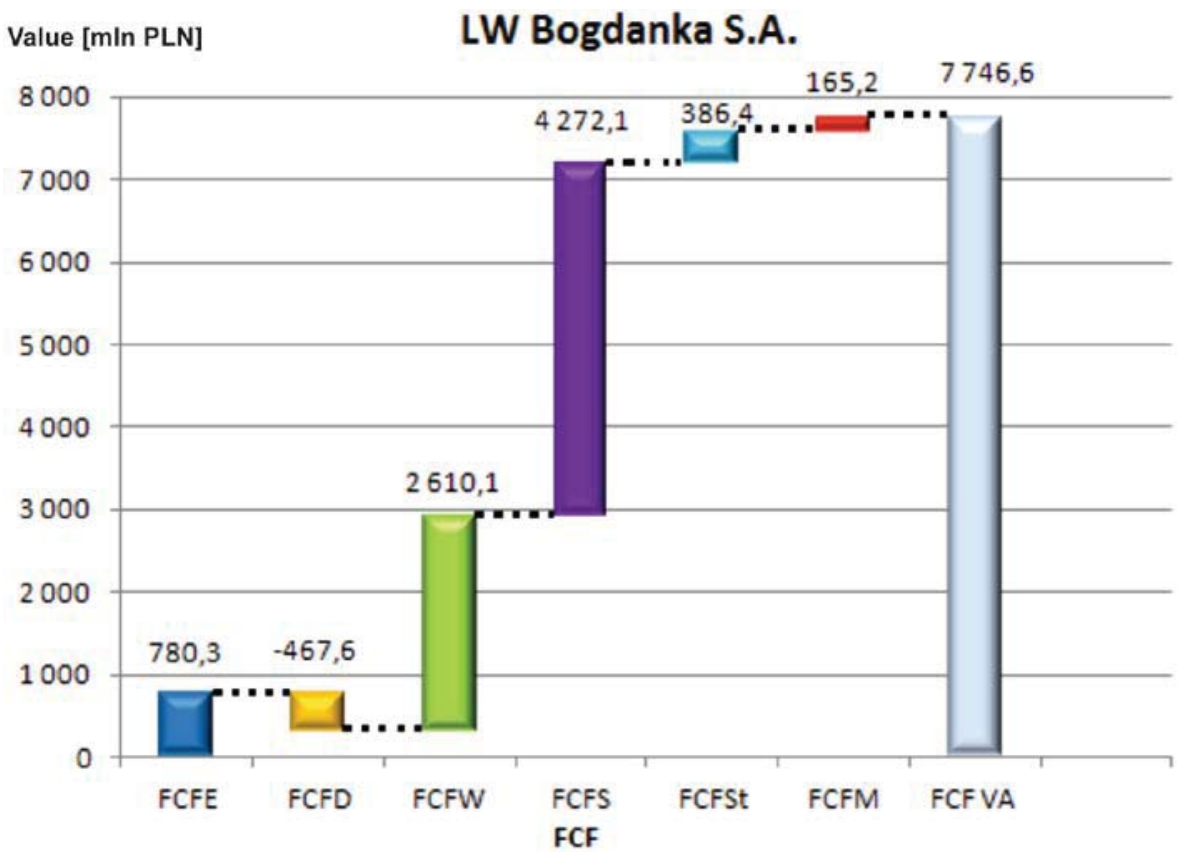

Fig. 8. Share of FCF for individual stakeholders in total FCF VA generated by LW Bogdanka S.A. Based on company data [11].

In terms of value distribution to all the stakeholders of LW Bogdanka S.A., the analysis shows that the suppliers had the biggest $(55 \%)$ share in value consumption. For the years in question, the total sharable amount that was payable to this group was PLN 4, 272.1 M.

In terms of earned profits, the employees are the second most benefiting group with the amount of PLN 2,610.1 M, which corresponds to a share of $34 \%$ of the total value. The trend in profit distribution is stable and suggests a steady growth. A minor decrease in remuneration and benefits for the staff was noted in 2015 and in 2016. 
The owners are the third largest group of beneficiaries of the value generated by LW Bogdanka. In the years 2011 to 2016 they received PLN 780.3 M in total. Their share reaches $10 \%$. With regard to this group, the biggest growth $(154 \%)$ occurred in the years 2011 to 2012.

The share of the country budget fluctuates at around $5 \%$. In the years that were examined, the Treasury's earnings from income tax amounted to PLN 165.2 M. The largest increase (44\%), was in the years 2011 to 2012, while the biggest decrease (34\%) was reported from the period of 2015 to 2016.

Municipalities received $2 \%$ of the total value from the company. As far as this interest group is concerned, there was a growth tendency in benefits such as taxes and fees that the businesses were charged in each year of the analysis. The years 2011 to 2012 had the biggest growth (34\%).

The smallest share in the benefits generated by the company belongs to the banks $(-6 \%)$. The negative value reported for this group comes from negatively generated cash flow.

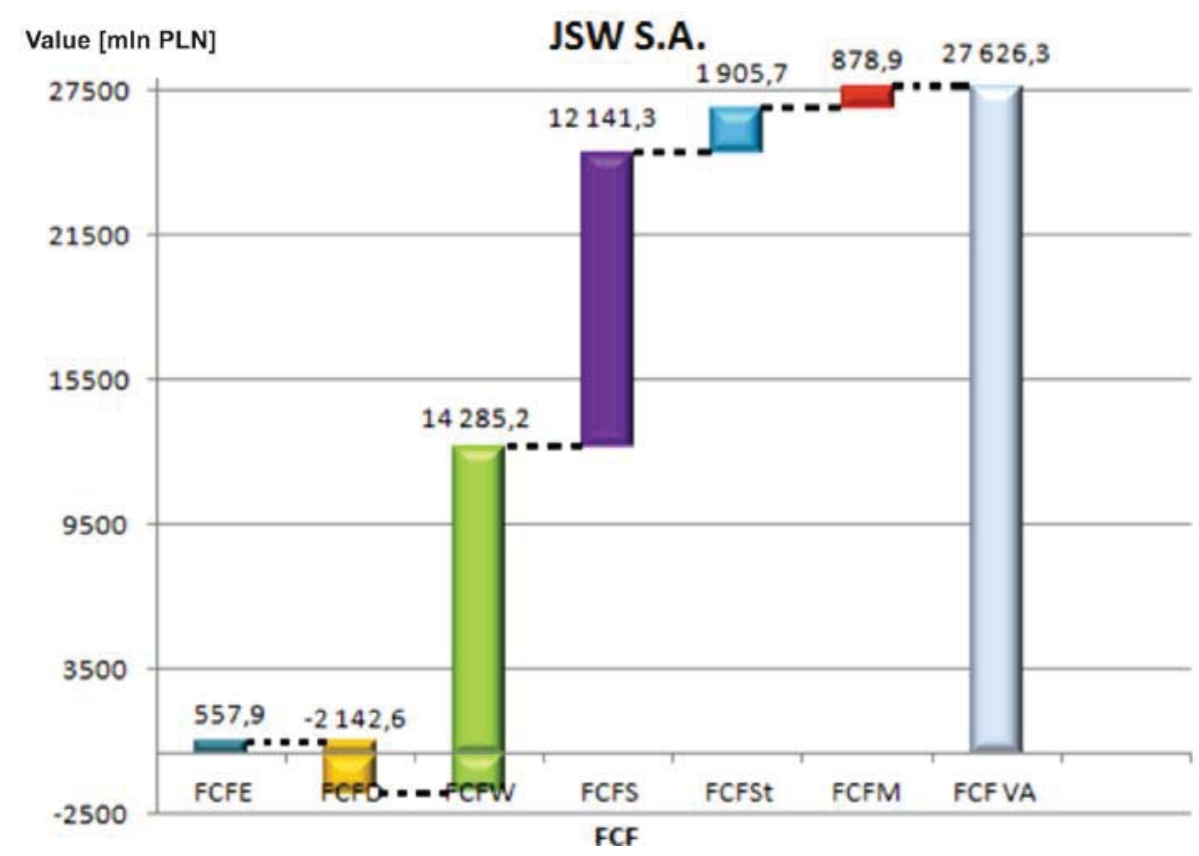

Fig. 9. Share of FCF for individual stakeholders in total FCF VA generated by JSW S.A. Based on company data [12].

The examination of JSW S.A. concluded that the largest share of the value generated by the company belonged to the staff $(52 \%)$. Within the examined years, the employees received a total of PLN 14, 285.2 M. In the years 2011 to 2016 there was a stable trend in value sharing and it was evenly distributed. A fall in this trend took place in the last year of the analysis, which meant a drop in value of $77 \%$. The most significant growth $(5.3 \%)$ was between 2014 and 2015.

The second best-benefitting group of the company's value is the suppliers (44\%). Thanks to the mutual relationship with JSW S.A., they gained a total benefit of PLN $12,141.3 \mathrm{M}$. For this group of stakeholders, a drop in profits $(15.4 \%)$ was recorded in the years 2012 to 2013 and between 2015 and 2016 (76\%).

The country budget share is around 7\%. The Treasury's gain from income tax between 2011 and 2015 reached PLN 1, 905.7 M. The biggest (104\%) drop in value happened between 2011 and 2012, as well as between 2015 and 2016 (98\%). Still, the highest value 
and, therefore, the largest tax payable to the state were in 2015. Between 2014 and 2015, the increase of value distribution for this interest group was $238 \%$.

The average obligatory liabilities affecting the results that go to the municipalities' budgets through extractive activities of JSW S.A. account for $3 \%$ of the value generated by the company and correspond to PLN 878.9 M.

The lowest share in the benefits generated by the company belongs to the owners $(2 \%)$ and the banks $(-8 \%)$.

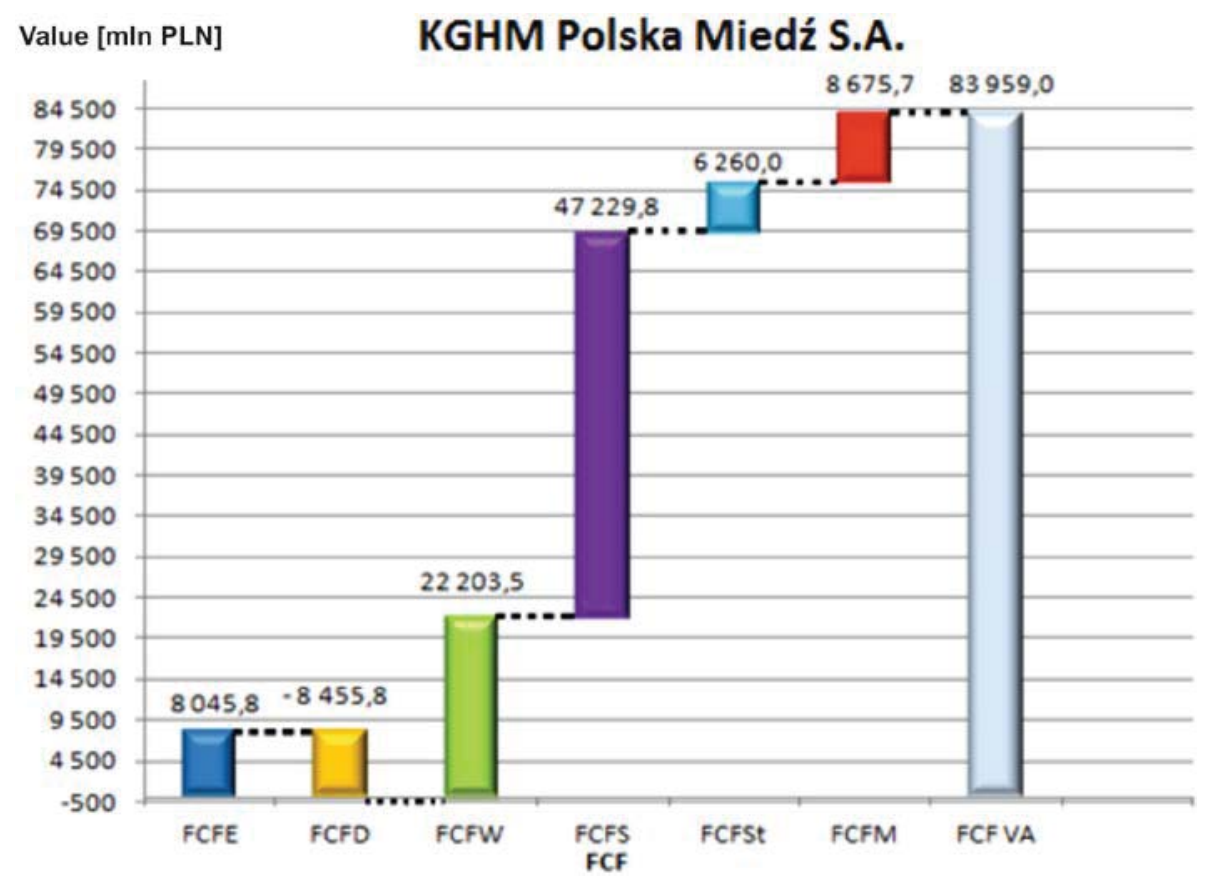

Fig. 10. Share of FCF for individual stakeholders in total FCF VA generated by KGHM Polska Miedź S.A. Based on company data [13].

The analysis of the value created by KGHM Polska Miedź S.A. shows that it is the suppliers who benefit the most from the relationship with the company (56\% of the value). In return for providing the company with supplies and power, as well as external services, they received an equivalent of PLN 47,229.8 M. The maximum increase (29\%) was observed between 2014 and 2015, whereas the biggest decrease (20\%) affected the years 2015 to 2016.

In terms of the value of the earned profits, the next interest group is represented by the employees. During the years that were subject to examination, the sum of remuneration and other benefits was PLN 22, 203.5 M. The employees' share in total value reaches $26 \%$. The biggest decrease (19\%) in payroll was noted between 2015 and 2016, while the years 2014 to 2015 saw the maximum increase of $29 \%$.

Municipalities are the third largest beneficiary of the value. The value distributed for them reached PLN 8, 675.7 M, which corresponded to $10 \%$ of the distributed profits.

The owners' shares are at the level of $9.5 \%$. All the profits that went to this group of the company's stakeholders were PLN $8045.8 \mathrm{~m}$. The years 2015 to 2016 were marked by the largest increase of 392\%. Conversely, the largest decrease (643\%) took place between 2013 and 2014, when positive values of cash flow changed to significantly negative ones.

Between 2011 and 2016, the country budget received a total of PLN 6, 260 M, which corresponded to approximately $7 \%$ of total profits. 
The banks were the least benefiting group of stakeholders from the relationship with the company, with the negative value of PLN $-8,455.8 \mathrm{M}$.

\section{Conclusions}

Creating a long-term value for all stakeholders is an objective that each enterprise should strive to reach, at the same time ensuring the company's economic success and an improvement of social and ecological results.

Distribution of added value in mining enterprises comes from the aspiration of meeting the needs of all the interest groups. The specificity of the sector determines the necessity of making socially responsible decisions which will meet the financial needs of the enterprise and improve the economic situation of the society. The ongoing crisis in the coal mining sector and the unprofitability of modern enterprises related to that call for an examination that would demonstrate the consequences of shutdowns and discontinuation of business activities. The study presented above shows that the effects of such decisions will be visible and palpable not only to the owners, but also to the staff, suppliers, financing institutions, the country budget and other stakeholders.

The analysis accounts for the contribution of LW Bogdanka S.A., JSW S.A. and KGHM Polska Miedź S.A. to both private and public incomes; moreover, it illustrates how these companies' business activities can be beneficial to the society. The findings show that for the years 2011 to 2016, KGHM Polska Miedź S.A. managed to be the most beneficial to its stakeholders because of achieving the highest FCF VA. At the same time, the process of value distribution shows that it is the staff and the suppliers who are most closely connected to all the businesses covered in this analysis. They benefit most financially from the enterprises and from their relationships with them. The banks, however, were the least benefiting group between 2011 and 2016. They provide the businesses with capital for investment and current activities, and the only benefit for them comes from interest payable to them. Thus, this mechanism results in creating a negative value for this group.

In terms of the ability to generate added value, the examination of the enterprises presented above demonstrates that each of the interest groups has its own, bigger or smaller, share in the consumption of the value, at the same time benefitting from the mutual relationship with the company. Based on the findings, one can point out those interest groups that will suffer most from the wrong decisions taken at the management board level. In such a case, the staff and the suppliers will be most negatively affected, while the banks will be the least disadvantaged.

This information leads to the conclusion that this analysis, which can be a part of the model for sustainable value assessment, can also be a kind of account addressed to the society that raises awareness of advantages offered by mining enterprises. This model may also serve as one of the premises that facilitate making strategic decisions on a shutdown or continuation of extractive activities taken by socially responsible mining companies - ones that, in the pursuit of economic effectiveness, take into account the needs and expectations of the environment. This is due to the fact that the enterprises that belong to strategic sectors have a bigger influence on their immediate and indirect environments and the whole society than traditional business partnerships. In light of this, making strategic decisions should not be based on financial analyses only, but also on the findings of this work, which allow for assessing a given company in terms of benefits that it creates for the society. This would make it possible to have a comprehensive and holistic view of the current situation of mining enterprises both at home and abroad. 


\section{References}

1. N. Hop, J. Kudełko, Dzieje górnictwa - element europejskiego dziedzictwa kultury, Oficyna Wydawnicza PWr, Wrocław (2013)

2. R.E Freeman, Strategic Management: A stakeholder Approach, Cambidge University Press, New York (2010)

3. J. Kulczycka, H. Wirth, Zeszyty Naukowe IGSMiE PAN, 79, Kraków (2010)

4. M. Marcinkowska, ZN USz, 693 (2011)

5. A. Kijewska and A. Bluszcz and A. Sojda, Metalurgija, 4 (2015)

6. B. Kowal, A. Kustra, E3S Web of Conferences, 10, (2016)

7. M.F. Morley, Accounting Rev, 3 (1979)

8. A. Riahi-Belkaouri, Value Added Reporting -Lessons for the United States, Quorum Books, New York (1992)

9. S. Lorenc, A. Kustra, IM, 2 (2016)

10. S. Lorenc, E3S Web of Conferences, 14 (2017)

11. http://www.ri.lw.com.pl/raporty-okresowe

12. https://www.jsw.pl/relacje-inwestorskie/raporty-gieldowe/raporty-okresowe/

13. http://kghm.com/pl/inwestorzy/prezentacje/raporty-finansowe 